DOI https://doi.org/10.32837/app.v0i65.317

УДК 327:339.924 (5) «19/20»

I. М. Милосердна

ORCID ID: https://orcid.org/0000-0003-2083-9500 кандидат політичних наук, доцент, доиент кафедри політичних теорій

Національного університету «Одеська юридична академія»

\author{
Т. М. Краснопольська \\ ORCID ID: https://orcid.org/0000-0001-5936-5889 \\ кандидат політичних наук, доцент, \\ доцент каредри політичних теорій \\ Наиіонального університету «Одеська юридична академія»
}

\title{
АЗІАТСЬКО-ТИХООКЕАНСЬКИЙ РЕГІОН ТА ПРОЄКТИ ЙОГО РОЗВИТКУ: КІНЕЦЬ ХХ - ПОЧАТОК ХХІ СТОЛІТТЯ
}

В умовах трансформації міжнародних відносин після руйнації біполярної системи процеси в Азіатсько-Тихоокеанському регіоні характеризуються поглибленням економічної взаємодії між державами, розвитком інтеграційних тенденцій у всьому їх різноманітті і переплетенні різних чинників. Проблема є актуальною, оскільки в політичній науці немає чітко окресленого єдиного підходу до поняття «Азіатсько-Тихоокеанський регіон» і визначення його рамок із географічного погляду, а також практична актуальність дослідження зумовлена інтеграційними процесами, які відбуваються в сучасній ієрархії глобального світу, де одне із провідних місць належить Азіатсько-Тихоокеанському регіону.

Отже, стаття має на меті узагальнення уявлень щодо сутності поняття «Азіатсько-Тихоокеанський регіон» і аналіз досвіду впровадження проєктів розвитку регіону в сучасних умовах.

Аналіз основних досліджень і публікацій дає можливість стверджувати, що в сучасній науці існує значна кількість робіт, які присвячені вивченню Азіатсько-Тихоакеанського регіону. Передусім варто зазначити таких закордонних і вітчизняних дослідників: Р. Балдвіна, Д. Камро, А. Санта-Круз, А. Каплінга, Ф. Дрисдейла, С. Мішину, Е. Фрост, В. Фостійчук, А. Богатурова, У. Ільницьку, Г. Костюніну, С. Мариніну, М. Лагутіну, А. Митрофанову, Такаші Тераді й ін.

Азіатсько-Тихоокеанський регіон (далі - АТР) у сучасних умовах виступає як активний і важливий суб'єкт сучасних геополітичних процесів і міжнародних відносин, проте серед дослідників і дотепер не існує єдиного підходу до поняття «АТР».

Прийнято вважати, що в АТР входять країни і регіони, що знаходяться як на західному узбережжі Тихого океану - країни Азії, так і на східному - країни Північної та Південної Америки. У південній частині Тихого океану розташовані Австралія, Нова Зеландія, а також малі острівні держави. В. Аміров, А. Канаєв, В. Міхеєв у роботі «Тихоокеанская Азия: экономические и политические последствия глобального финансового кризиса» використовують поняття «Тихоокеанська Азія», під яким пропонують розуміти «політико-географічне і геоекономічне поняття, що включає регіон в західній частині Тихоокеанського басейну від Тихоокеанської частини Росії на півночі до Нової Зеландії на південь (включає також Японію, Китай, Папуа - Нову Гвінею). Тихоокеанська Азія є еквівалентом Азіатсько-Тихоокеанського регіону в його строго географічних рамках» (Аміров та ін., 2010, с. 4).

На думку С. Мішина, варто виокремлювати три підходи до визначення АТP, а саме: політичний, географічний і економічний. Для прибічників першого підходу визначення меж регіону не є принциповим завданням, їм важлива сама ідея. Обгрунтування цілісності та складу АТР висуваються представниками двох інших підходів. 3 географічного погляду «АТР» - не визначене поняття, головна трудність полягає у визначенні його рамок, оскільки від цього безпосередньо залежить включення до складу регіону низки країн і субрегіонів: Північної і Латинської Америки, Росії або тільки ії Далекосхідного регіону тощо.

В. Фостійчук спирається на географічний і воєнно-стратегічний підхід і визначає так склад АТР: 
- Північно-Східна Азія (6 держав і одна територія);

- Південно-Східна Азія (11 держав);

- держави тихоокеанського узбережжя Північної Америки (2 держави);

- Австралія і країни Океанії (14 держав і 15 територій);

- Тихоокеанська Латинська Америка (11 держав).

Також вона виокремила засади для класифікації підходів до ролі регіону в сучасній глобальній геополітичній структурі, серед яких означені такі: залежно від географічної єдності; залежно від економічної розвиненості і динамізму; з погляду воєнно-стратегічного поділу регіону на театри військових дій, стратегічні напрями, стратегічні райони, оперативні командування; залежно від політичної кон'юнктури, пов'язаної із проблемами гарантування національної безпеки держав; за політичною однорідністю країн, що входять у субрегіони; 3 погляду участі в діяльності міжнародних регіональних організацій (Фостійчук, 2005).

Американська дослідниця Еллен Фрост у роботі «Новий азіатський регіоналізм» досліджує поняття «АТР» у контексті системи концентричних кіл. Внутрішнє коло утворює первинна п'ятірка Асоціації держав Південно-Східної Азії (далі - АСЕАН) (Індонезія, Малайзія, Філіппіни, Сінгапур, Таїланд), друге коло - АСЕАН «у форматі десяти (на додаток до перелічених - Бруней, Камбоджа, Лаос, М'янма і В'єтнам), третє коло - «АСЕАН + 3» (Китай, Південна Корея, Японія). Під зовнішнім колом АТР Е. Фрост розуміє консультативну систему Східноазіатського саміту, метою якого $є$ підготовка грунту для створення Східноазіатського співтовариства у складі АСЕАН + 3, а також Австралії, Індії та Нової Зеландії» (Фрост, 2008).

Отже, визначення території і кордонів АТР становить для вчених певну трудність. Деякі експерти говорять про АТР як регіон, який складається із країн ПСА, ПСА, Океанії (приблизно 20) і країн Південної Азії. Інші включають у нього тільки азіатські країни, що виходять на Тихий океан. Океанічний підхід припускає, що в АТР включаються країни, розташовані на узбережжі й островах Тихого океану: Північна, Центральна і Тихоокеанська Південна Америка (в останньому випадку держави, розташовані на берегах Тихого океану), південна частина Тихого океану, ПСА або Далекий Схід і частина ПСА.

Варто зазначити, що існує і вузьке поняття «АТР», за допомогою якого пояснюють включення в регіон тільки азіатських держав. Це країни Північно-Східної Азії: Китай, Японія, Південна і Північна Корея, десять країн Південно-Східної Азії, об'єднаних у регіональну організацію АСЕАН (Шергін, 2004). У статті використовується власне вузьке тлумачення АТР. Усі країни мають певну роль і вплив у регіоні, але динамічними, на наш погляд, виступають країни Східної Азії, як-от Китайська Народна Республіка (далі - КНР), Японія, Північна і Південна Корея. Крім того, на регіональні процеси в АТР ітостно впливають Сполучені Штати Америки (далі - США). Усі ці країни роблять значний внесок у міждержавні відносини в Тихому океані, тому тенденції стабільності переважають над тенденціями дестабілізації політичних і економічних процесів, які формують основу потенційного світового центру.

Що стосується характеристики проєктів розвитку співробітництва в АТР в умовах кінця XX - початку XXI ст., то треба зазначити, що цей хронологічний період характеризується переходом від біполярної системи міжнародних відносин до глобалістської, що сприяло становленню нестійкості та суперечності геополітичної ситуації у світі. На тлі геоекономічного розшарування світу починають виразно формуватися макрорегіональні простори, збільшується кількість соціально-економічних коаліцій і союзів, формується система глобального управління ресурсами планети й усієї економічної діяльності на ній.

Отже, якщо продовжувати думку С. Гантінгтона, закінчення холодної війни стало періодом становлення нової фази міжнародної політики, у яку буде активніше залучена більшість цивілізацій (держав), згідно з його класифікацією, яка приведе новий міжнародний порядок до конфлікту, зокрема, за культурно-релігійним розділенням і цивілізаційною приналежністю, наприклад, Заходу з ісламським світом, Росії із Заходом та ін. Вплив цивілізаційного чинника на світову політику після закінчення холодної війни С. Гантінгтон бачить у появі «синдрому братських країн». Окрім цього, як приклад реальності цивілізаційних відмінностей він вказує на те, що основні конфлікти останніх років відбувалися на лініях розлому між цивілізаціями (Балкани, Кавказ, Близький Схід тощо) (Гантінгтон, 2006, с. 76). 
Після завершення холодної війни АТР можна було вважати найстабільнішим регіоном у світі, який пройшов період тривалого економічного розвитку без очевидних конфліктів. Проте останніми роками, з ескалацією ситуації навколо островів Дяоюйдао у Східно-Китайському морі і територіальних суперечок у Південно-Китайському морі, стурбованість щодо напруженості, що посилюється, і геополітичних конфліктів в цьому регіоні росте. Передусім тому, що всі ці питання пов'язані із двома найбільшими країнами - Китаєм і США, хоча, як говорить голова КНР Сі Цзиньпін, «величезний Тихий океан має досить простору для розвитку як Китаю, так і США» (Цзиньпін, 2014, с. 55).

Варто зазначити, що АТР вступив на шлях розвитку інтеграційних процесів набагато пізніше за інші регіони світу (за винятком АСЕАН, створеної у другій половині 60-х рр.). Уперше в 1965 р. відомий японський економіст К. Кодзима сформулював ідею створення Тихоокеанської зони вільної торгівлі (далі - ПАФТА) за участю п'яти держав - США, Канади, Японії, Австралії та Нової Зеландії. Передбачалося надання торгових преференцій державам, які розвиваються, розширення координації двосторонньої фінансової допомоги розвиненими країнами державам, що розвиваються.

Але ідея не була реалізована з об'єктивних причин, зокрема із-за відмови країн, що розвиваються, які побачили в ній спробу зберегти економічний тиск із боку розвиненіших держав. У 60-80-і рр. інституціоналізація економічного співробітництва в регіоні пішла шляхом утворення неурядових організацій - Тихоокеанської конференції $з$ торгівлі і розвитку (далі ПЛФТЛД), Тихоокеанської економічної ради (далі - ТЕС), Ради з тихоокеанського економічного співробітництва (далі - СТЕС), головним ініціатором яких стала Японія. Також варто зазначити, що в цей період успіхи в інтеграційній взаємодії країн АСЕАН виявилися мінімальними: була створена лише зона преференційної торгівлі та сформовано декілька спільних виробничих об'єктів, тобто АСЕАН повторив приклад численних спроб країн різних континентів, які розвиваються, інтегруватися в умовах низького рівня економічного розвитку, за відсутності або принаймні невеликої економічної взаємозалежності та взаємодоповнення, монокультурності економічної структури.

Загалом кінець 80-х рр. знаменувався посиленням економічної взаємозалежності, поглибленням регіональної економічної інтеграції, що привело до зміщення організаційних основ економічного співробітництва в АТР від суто консультативних рамок до спроби створення загальнорегіонального угруповання й інтенсифікації субрегіональної інтеграції. Водночас у регіоні зберігаються такі сильні чинники, як: велика економічна, політична та соціально-культурна диференціація країн, відсутність єдиної загальнорегіональної ідеї, менталітет азіатських народів, які не вважають себе єдиною нацією, а також різні політичні цілі участі в єдиному блоці. Характерними рисами азіатсько-тихоокеанської інтеграції є: поширення мікроекономічної інтеграції завдяки японським і американським ТНК, ії пріоритет перед макроекономічною інтеграцією; переплетіння інтегруючих і дезінтегруючих чинників на регіональному і субрегіональному рівнях сприяло появі м' якої форми інтеграції, яка мала прояв у зонах економічного зростання у Східній Азії та в рамках АТЕС; пріоритет субрегіональної інтеграції над регіональними інтеграційними тенденціями через мінімізацію впливу дезінтегруючих чинників і переважання інтегруючих чинників; прихильність до принципу відкритого регіоналізму, який набув офіційного визнання в 1992 р.; формування зони вільної торгівлі в рамках Форуму АТЕС на основі принципів невзаємності, добровільності та консенсусу.

Наступним переломним етапом в інтеграційних процесах регіону є досягнуті успіхи в економічному розвитку в 1990-і рр., в умовах загрози розколу світу на декілька регіональних блоків, загострення конкуренції на світових ринках у країнах АСЕАН підвищився інтерес до поглиблення інтеграційних тенденцій. У результаті в 1992 р. на саміті в Сінгапурі ухвалено рішення про створення зони вільної торгівлі товарами і послугами (далі - ЗВТ), а в 1998 р. про формування інвестиційної зони в цілях підвищення привабливості регіону для закордонних капіталовкладень на основі об'єднання розрізнених національних ринків в єдиний ринок, вільний від обмежень.

Як уже зазначалось, один із феноменів азіатсько-тихоокеанської економічної інтеграції - наявність м'яких схем інтеграції, які знайшли прояв у формуванні зон економічного 
зростання у Східній Азії. Поглиблення господарської інтернаціоналізації на загальнорегіональному рівні сприяло створенню першої урядової економічної організації - Форуму «Азіатсько-тихоокеанське економічне співробітництво» (далі - АТЕС), який об'єднав 21 державу. Принципова відмінність АТЕС від інших регіональних і міжнародних структур полягає в підході до торгової й інвестиційної лібералізації на добровільній і невзаємній основі. АТЕС не зв'язує країни-члени взаємними зобов'язаннями щодо зниження торгових обмежень та гармонізації правил, має свої переваги й недоліки. Основні переваги: торгова й інвестиційна лібералізація на односторонній основі, яка дозволяє враховувати різні рівні економічного розвитку; сприяння поглибленню взаємного економічного співробітництва; вирішення спірних політичних питань (зокрема, між КНР і Тайванем, численні територіальні спори). Недоліки діяльності Форуму пов'язані з неоднозначною оцінкою його ефективності та здатності завершити реалізацію Богорської мети (Богорська декларація 1994 р., де зазначено такі цілі: досягнення вільної та відкритої торгівлі й інвестицій в АТР для розвинених країн до 2010 р., для держав, які розвиваються, - до 2020 р.; сприяння торгівлі й інвестиціям; активізація взаємного економічного співробітництва). Особливими заходами визначено прогресивне зниження ставок митних зборів, нетарифних обмежень і обмежень у торгівлі послугами (Костюніна, 2012, с. 36). Головний сумнів - принципи односторонньої та невзаємної лібералізації (проти яких виступають економічні лідери - Японія та США). Ці принципи прийнятні для більшості партнерів, але їхня практична ефективність досі не доведена. У зв' язку із цим багато експертів пропонують перейти на преференційну основу економічної інтеграції, але і цьому заважають суперечності між країнами щодо чутливих секторів - сільськогосподарської продукції (азіатські держави) і екологічних товарів (США).

Отже, проведений аналіз особливостей становлення регіоналізації в АТР дає можливість погодитися з О. Боготуровим у тому, що регіональна структура азіатської частини АТР формувалася за просторовим принципом. Він почав складатися ще в період холодної війни i був пов' язаний із прагненням малих і середніх країн регіону створити такі умови, за якими конфронтаційні імпульси держав-лідерів міжнародної системи «гасилися» б колективними зусиллями малих і середніх гравців. Просторова регіональна систем давала відносно рівні можливості гравцям різного рівня, включаючи Японію, Китай (що активно заявив про себе в регіональних справах із кінця 1990-х рр.), Південну Корею, Індію, Росію (Богатуров, 1997).

В інтересах малих і середніх держав було залучено якомога більше учасників, здатних політично урівноважити один одного і запропонувати вигідні економічні ініціативи. Залучення зовнішніх гравців відбувалося в умовах відносного силового вакууму, що означав відсутність яскраво вираженої боротьби за політичний вплив у регіоні (Колдунова, 2011). Політична боротьба пом'якшувалася механізмами регіональної співпраці, рушійною силою яких якраз і виступали малі та середні країни.

На рубежі 1990-2000-х рр., із становленням постбіполярної системи інтеграційний процес активізувався. Згідно з даними Азіатського банку розвитку, кількість інтеграційних об' єднань зросла із 3 у 2000 р. до 54 у 2007 р., 3 них 40 об'єднань реально функціонують, ще 78 угод перебувають на стадії переговорного процесу. Якщо підрахувати кількість інтеграційних об'єднань із розрахунку на одну державу, то цей показник щільності інтеграційних об'єднань становить 3,4 в Азії i, для порівняння, в Америці - 2,2. Найбільш активні у створенні регіональних інтеграційних об'єднань такі держави регіону, як Сінгапур (18 угод), Японія (11) і Китай (10).

Серед основних чинників, які сприяють динаміці інтеграційних ініціатив у регіоні, можна виділити такі:

- динамічне економічне зростання в державах регіону;

- показовий ефект успішності інтеграційних процесів в Свропі і Північній Америці;

- наслідки азіатської фінансової кризи кінця 90-х рр.;

- складнощі торгової лібералізації на багатосторонньому рівні в рамках СОТ.

Також одним із чинників, який сприяв інтенсивним інтеграційним процесам, можна вважати те, що на межі 1990-2000-х рр. на позиції регіонального лідера у Східній Азії поступово став висуватися Китай. Одним із зовнішньополітичних пріоритетів він проголосив формування «поясу добросусідства» за периметр своїх меж, тим самим розпочав процес нормалізації 
відносин із сусідніми державами (Лін та ін., 2005). Крім того, Китай активізував свої дії в регіональних інститутах співпраці і навіть виступив ініціатором створення таких нових економічних форматів, як «Форум Боао», а також різних фінансово-економічних фондів по лінії Китай - Південно-Східна Азія і Китай - Центральна Азія.

Окрім зони вільної торгівлі всередині АСЕАН, була впроваджена ЗВТ АСЕАН - Китай. До 2010 р. іiі основні завдання були реалізовані на 97\% у відносинах між Китаєм і групою АСЕАН-6 (Бруней, Індонезія, Малайзія, Філіппіни, Сінгапур, Таїланд). В'єтнам, Камбоджа, Лаос і М'янма запланували повністю виконати зобов'язання за угодою про ЗВТ до 2015 р. (ASEAN-China Dialogue Relations, 2010).

Важливу роль у посиленні азіатського регіоналізму відіграв діалоговий механізм АСЕАН + 3 у складі країн АСЕАН, Японії, Республіки Корея і Китаю, який ініціював формування Східноазіатського саміту. У 2005 р. відбувся перший Східноазіатський саміт у столиці Малайзії, м. Куала-Лумпур у складі 16 держав АСЕАН-10, Японії, Китаю, Республіки Корея, Австралії, Нової Зеландії й Індії. Статус спостерігача має Російська Федерація. На саміті було ухвалено стратегічне рішення про формування Східноазіатської економічної спільноти - BAЕС (East Asian Economic Community) до 2020 р. Розроблені декілька моделей ВАEC, зокрема за формулами АСЕАН + 6, АСЕАН + 3, АСЕАН + 1 + 1 + 1 .

У 2009 р. на зустрічі міністрів економіки АСЕАН була підтверджена рішучість створити найбілышу у світі зону вільної торгівлі на поетапній основі, а Східноазіатське Співтовариство може стати дієвим інструментом формування більшого інтеграційного об'єднання - зони вільної торгівлі в Азіатсько-Тихоокеанському регіоні в рамках концепції ФТААП (Free Trade Area for Asia Pacific - FTAAP). У 2004 р. Консультативною радою АТЕС був запропонований проєкт Азіатсько-Тихоокеанської зони вільної торгівлі (ФТААП), головними прибічниками якого стали США за підтримки Японії, Австралії, Канади та Мексики, тобто держав, які традиційно підтримують зовнішню політику американської адміністрації в Азіатсько-Тихоокеанському регіоні впродовж останніх років. Ця ініціатива була затверджена на Ханойському саміті ATEC у 2006 р. Головними причинами розроблення концепції ФТААП видаються такі:

- швидке зростання нових інтеграційних об'єднань в АТР на субрегіональному рівні та у двосторонніх рамках, які в перспективі можна об'єднати в ширше інтеграційне об'єднання;

- складнощі завершення першого раунду багатосторонніх торгових переговорів у рамках СОТ, відомого як Дохійський раунд (охоплює питання сільського господарства, доступу на ринки промислових товарів, послуг, правил торгівлі, спрощення торгових процедур, прав інтелектуальної власності, торгівлі й екології, поліпшення механізму регулювання торгових суперечок, спеціального і диференційованого режиму (Холодков, 2014, с. 154);

- сприятлива політична й економічна ситуація для формування інтеграційної архітектури у формі «тріади» Европейського Союзу, НАФТА та зони вільної торгівлі в АТР. Подібна концепція була проголошена на межі 80-90-х рр. минулого століття і навіть заслухана в Конгресі США;

- збереження важливості АТЕС як єдиного багатостороннього форуму, що зв'язує держави по обидві сторони Тихоокеанського басейну, і для США, і для провідних східноазіатських держав (Костюніна, 2011, с. 40).

Аналіз інтеграційної співпраці в АТР в умовах руйнації біполярної системи міжнародних відносин дає можливість також говорити про наявність трендів політичного регіоналізму в азіатській частині АТР.

Перший тренд пов'язується з посиленням ролі Китаю в регіональному політичному процесі. Співпраця Китаю з АСЕАН сьогодні $є$ важливою політичною картою, оскільки служить доказом його мирного, нікому не загрозливого зростання, концепція якого з'явилася після візиту Чжен Бідзяна у США у 2002 р. У свою чергу, держави ПСА можуть розраховувати на переваги у виході на внутрішній китайський ринок, а також на пільгову торгівлю Китаю 3 найменш розвиненими країнами регіону - М'янмою, Лаосом та Камбоджою. Нерідко регіоналізація та глобалізація розглядаються сьогодні Пекіном як процеси, що доповнюють один одного. I тому зростаючу інтеграцію Китаю зі східноазіатськими сусідами окремі дослідники називають «глобалізацією китайської економіки». Проте дослідження позарегіональної 
активності Китаю (зокрема, його співпраця з Австралією, Індією й Африканським континентом) дають можливість зробити висновок про його орієнтованість на побудову самостійного виробничо-економічного комплексу.

Другий тренд азіатського регіоналіму пов'язаний зі співіснуванням двох моделей співпраці в регіоні: транснаціональної кооперації (ії пропонує ПСА) і міждержавної конкуренції (цим шляхом ідуть держави ПСА). Витрати другої моделі автор пропонує простежити на прикладі китайсько-японських стосунків. Сутність суперництва двох східноазіатських сусідів сьогодні зводиться до того, хто з них успішніше і швидше зможе увійти до системи регіональної кооперації через співпрацю у формулі АСЕАН + 1. Тоді як зараз найбільш адекватним і корисним для розвитку регіону було б спільне лідерство Японії та Китаю на основі конструктивного діалогу.

Третій тренд у розвитку східноазіатського регіоналізму пов'язаний із тим, що закінчення В'єтнамської війни переносить фокус у питаннях регіональної безпеки із зовнішніх загроз на внутрішні, і на перший план виходять аспекти політичної, економічної, соціальної й екологічної співпраці. Для обговорення їх був створений Регіональний форум АСЕАН (далі - РФА), ідея якого з' явилася незабаром після створення АТЕС, а інституціональне оформлення відбувалося паралельно зі створенням НАФТА. Метою створення РФА проголошувалося розроблення механізмів вирішення конфліктів, але під натиском Китаю первинне формулювання мети було змінене на «розроблення підходів, що менш зобов' язує, до конфліктів». Вдалим приводом для усунення США від регіональної політики є одна із трьох умов щодо участі в Асоціації: вимога про укладення Договору про мир і дружбу з АСЕАН, що робить акцент на мирному, невоєнному характері співпраці. Відмова Пентагону підписувати цей Договір стала причиною відсутності США на Самітах східноазіатських держав - нової структури регіонального партнерства.

Висновки. Аналіз проєктів розвитку співробітництва в АТР наприкінці $X X$ - на початку XXI ст. в умовах формування постбіполярної системи міжнародних відносин дозволяє говорити про те, що в регіоні відбувається інтенсивне формування регіональних форумів і механізмів, що сприяє тісним відносинам між основними суб'єктами регіону і посиленню його позицій у світовому політичному процесі.

Міждержавна співпраця АТР відіграє значну роль у відносинах між державами, а їх інтеграція виражена у створенні різних економічних і політичних об'єднань, серед яких найбільш значущі Асоціація держав Південно-Східної Азії (АСЕАН) та Азіатсько-Тихоокеанське економічне співробітництво (АТЕС).

Важливим економічним об'єднанням є АСЕАН - інтеграційне об'єднання країн ПівденноСхідної Азії. Організація була створена 8 серпня 1967 р. в Бангкоку за ініціативою п'яти країн: Сінгапуру, Індонезії, Філіппін, Таїланду та Малайзії. Пізніше до складу цього угруповання ввійшли всі країни регіону. Успіх взаємної співпраці цієї організації пов'язаний із бурхливим економічним зростанням у країнах, що входять в АТР. Це сприяло найважливішим крокам зі створення проєктів у рамках АТР (Зона вільної торгівлі АСЕАН (АФТА), Зона інвестиції АСЕАН (AIA), схеми промислової співпраці АСЕАН).

Окрім АСЕАН, нині найбільш впливовою економічною організацією в АТР є Форум Азіатсько-Тихоокеанського економічного співробітництва, який був створений ще в 1989 р. У АТЕС входять країни, на які загалом припадає велика частина всього світового валового внутрішнього продукту. Вони прагнуть до забезпечення процвітання народів регіону. Головними завданнями АТЕС є забезпечення режиму вільної торгівлі, зміцнення регіональної співпраці, створення ліберального інвестиційного режиму.

\section{Лimepamypa:}

Богатуров А. Великие державы на Тихом океане. Москва : Конверт-МОНФ, 1997. 353 с.

Гантінгтон С. Протистояння цивілізацій та зміна світового порядку. Пер. з англ. Н. Климчук. Львів : Кальварія, 2006. 474 с.

Колдунова Е. Дефицит лидерства в Восточной Азии: шансы для малых и средних стран. Международные проиессы. 2011. № 2(26). С. 70-81.

Костюнина Г. АТЭС: институциональная структура, направления деятельности и достижения. Российский внешнеэкономический вестник. 2012. № 10. C. 33-46. URL: https://mgimo.ru/upload/iblock/dc0/ dc0ac11357d9aac421ada14e87fa17a2.pdf. 
Костюнина Г. Регионализация Восточной Азии: истоки и основные модели. Вестник Московского государственного института международных отношений. 2011. № 1. С. 34-42.

Тихоокеанская Азия: экономические и политические последствия глобального финансового кризиса / отв. ред. : В. Амиров, Е. Канаев, В. Михеев. Москва : ИМЭМО РАН, 2010. 135 с.

Фостийчук В. Геополитические процессы в Азиатско-Тихоокеанском регионе и их влияние на обеспечение национальной безопасности Российской Федерации : автореф. дис. .... канд. полит. наук: 23.00.02. 2005. URL: http://cheloveknauka.com/geopoliticheskie-protsessy-v-aziatsko-tihookeanskom-regione-i-ihvliyanie-na-obespechenie-natsionalnoy-bezopasnosti-rossi\#ixzz5koqDQOkk.

Фрост Э. Новый азиатский регионализм. Лондон : Изд-во Линн Рьеннер, 2008. 293 с.

Холодков В. Основные проблемы Дохийского раунда многосторонних торговых переговоров в рамках ВТО и интересы России. Проблемы национальной стратеги. 2014. № 1(22). С. 153-166.

Цзиньпин Си. О государственном управлении. Пекин : Изд-во лит. на иностр. яз., 2014. 630 с.

Шергин С. Азиатско-тихоокеанская дилемма. Зеркало недели. 2004. № 32. URL: https://zn.ua/ ECONOMICS/aziatsko-tihookeanskaya_dilemma.html.

ASEAN-China Dialogue Relations. ASEAN. URL: http://my.china-embassy.org/eng/zt/eastasia/jzjk/t771055.htm. Baldwin R. $21^{\text {st }}$ century regionalism: Filling the gap between $21^{\text {st }}$ century trade and $20^{\text {th }}$ century trade rules. CEPR Policy Insight 56. 2011. URL: https://www.wto.org/english/res_e/reser_e/ersd201108_e.pdf.

Camroux David, Frederic Chasing Pavements. The East Asia Summit and the Trans-Pacific Partnership, Discursive Regionalism as Disguised Multilateralism. September 2011. URL: https://hal-sciencespo.archives-ouvertes.fr/ hal-01069507/document.

Santa-Cruz A. Out of the Blue: The Pacific Rim as a Region. Portal Journal of Multidisciplinary International Studies. 2005. Vol. 2. № 2. July. URL: https://epress.lib.uts.edu.au/journals/index.php/portal/article/ view/107.

China's "Good Neighbor" Diplomacy: A Wolf in Sheep's Clothing? / G. Lin et al. Woodrow Wilson International Center for Scholars Asia Program Special Report/ 2005. № 126. URL: https://www.wilsoncenter.org/sites/ default/files/media/documents/publication/ASIAreport_No126.pdf.

The Asian Development Bank. URL: https://www.adb.org/.

\section{References}

Bogaturov A.D. Velikie derzhavy na Tikhom okeane [Great powers in the Pacific]. M.: Konvert-MONF, 1997. 353 s. [in Russian]

Gantington S. Protistoyannya tsivilizatsiy ta zmina svitovogo poryadku / pereklad z angliys'koï N. Klimchuk [Confrontation of civilizations and change of world order / translated from English by N. Klimchuk]. L'viv: Kal'variya, 2006. 474 s. [in Ukrainian]

Koldunova E.V. Defitsit liderstva v Vostochnoy Azii: shansy dlya malykh i srednikh stran [Leadership Deficit in East Asia: Opportunities for Small and Medium Countries]. Mezhdunarodnye protsessy [International processes]. 2011. № 2(26). S. 70-81. [in Russian]

Kostyunina G.M. ATES: institutsional'naya struktura, napravleniya deyatel'nosti i dostizheniya [APEC: institutional structure, lines of activity and achievements]. Rossiyskiy vneshneekonomicheskiy vestnik [Russian Foreign Economic Bulletin]. 2012. № 10. S. 33-46. URL: https://mgimo.ru/upload/iblock/dc0/dc0ac11357d 9aac421ada14e87fa17a2.pdf [in Russian]

Kostyunina G.M. Regionalizatsiya Vostochnoy Azii: istoki i osnovnye modeli [Regionalization of East Asia: the origins and basic models]. Vestnik MGIMO [Bulletin of MGIMO]. 2011. № 1. S. 34-42. [in Russian]

Tikhookeanskaya Aziya: ekonomicheskie i politicheskie posledstviya global'nogo finansovogo krizisa / Otv. red. V.B. Amirov, E.A. Kanaev, V.V. Mikheev [Pacific Asia: Economic and Political Consequences of the Global Financial Crisis / Ed. ed. V.B. Amirov, E.A. Kanaev, V.V. Mikheev]. M.: IMEMO RAN. 2010. 135 p. [in Russian] Fostiychuk V.V. Geopoliticheskie protsessy v Aziatsko-Tikhookeanskom regione i ikh vliyanie na obespechenie natsional'noy bezopasnosti Rossiyskoy Federatsii / avtoreferat dis. ... kandidata politicheskikh nauk : 23.00.02 [Mesto zashchity: Diplomat. akad. MID RF] 2005 [Geopolitical processes in the Asia-Pacific region and their impact on ensuring the national security of the Russian Federation / abstract dis. ... candidate of political sciences: 23.00.02 [Place of defense: Diplomat. akad. Ministry of Foreign Affairs of the Russian Federation] 2005]. URL: http:/ / cheloveknauka.com/geopoliticheskie-protsessy-v-aziatsko-tihookeanskom-regione-i-ih-vliyanie-na-obespechenie-natsionalnoy-bezopasnosti-rossi\#ixzz5koqDQOkk. [in Russian]

Frost E.L. Novyy aziatskiy regionalizm [New Asian regionalism]. London: Izd-vo Linn R'enner. 2008.293 s. [in Russian]

Kholodkov V.M. Osnovnye problemy Dokhiyskogo raunda mnogostoronnikh torgovykh peregovorov $\mathrm{v}$ ramkakh VTO i interesy Rossii [The main problems of the Doha round of multilateral trade negotiations within the WTO and Russia's interests]. Problemy natsional'noy strategi [Problems of the national strategist]. 2014. № 1(22). S. 153-166. [in Russian] 
Tszin' pin Si O gosudarstvennom upravlenii [On public administration]. Pekin: Izd-vo lit. na inostr. yaz., 2014. 630 s. [in Russian]

Shergin S. Aziatsko-tikhookeanskaya dilemma [The Asia-Pacific Dilemma.]. Zerkalo nedeli [The mirror of the week]. 2004. № 32. URL: https:/ / zn.ua/ECONOMICS/aziatsko-tihookeanskaya_dilemma.html. [in Russian] ASEAN-China Dialogue Relations. ASEAN. URL: http://my.china-embassy.org/eng/zt/eastasia/jzjk/ t771055.htm [in English]

Baldwin R. $21^{\text {st }}$ century regionalism: Filling the gap between $21^{\text {st }}$ century trade and $20^{\text {th }}$ century trade rules. CEPR Policy Insight 56. 2011. URL: https://www.wto.org/english/res_e/reser_e/ersd201108_e.pdf. [in English]

Camroux David, Frederic Chasing Pavements: The East Asia Summit and the Trans-Pacific Partnership, Discursive Regionalism as Disguised Multilateralism. September 2011. // https://hal-sciencespo.archivesouvertes.fr/hal-01069507/document. [in English]

Santa-Cruz A. Out of the Blue: The Pacific Rim as a Region. Portal Journal of Multidisciplinary International Studies. 2005. - Vol. 2. - № 2 July. URL: https://epress.lib.uts.edu.au/journals/index.php/portal/article/ view/107. [in English]

Lin G., Garver J., Hickey D., Chambers M. China's “Good Neighbor” Diplomacy: A Wolf in Sheep’s Clothing? / Woodrow Wilson International Center for Scholars Asia Program Special Report, 2005. № 126. URL: https://www. wilsoncenter.org/sites/default/files/media/documents/publication/ASIAreport_No126.pdf. [in English]

The Asian Development Bank. URL: https://www.adb.org. [in English]

\section{Анотація}

Милосердна I. М., Краснопольсъка Т. М. Азіатсько-Тихоокеанський регіон та проєкти його розвитку: кінець XX - початок XXI століття. - Стаття.

Стаття присвячена комплексному дослідженню сутності розуміння поняття «Азіатсько-Тихоокеанський регіон», аналізу досвіду впровадження проєктів розвитку регіону в сучасних умовах. Встановлено, що серед дослідників і дотепер не існує єдиного підходу до поняття «АТР». У межах статті термін «АТР» уживається у вузькому значенні: це країни Північно-Східної Азії: Китай, Японія, Південна і Північна Корея, десять країн Південно-Східної Азії, об'єднаних у регіональну організацію - Асоціацію держав Південно-Східної Азії. Усі ці країни вносять значний вклад у міждержавні відносини в Тихому океані, тому тенденції стабільності переважають над тенденціями дестабілізації політичних і економічних процесів, які формують основу потенційного світового центру. Встановлено, що після завершення холодної війни Азіатсько-Тихоокеанський регіон можна було вважати найстабільнішим регіоном у світі, який пройшов період тривалого економічного розвитку без очевидних конфліктів. Зазначено, що Азіатсько-Тихоокеанський регіон вступив на шлях розвитку інтеграційних процесів набагато пізніше за інші регіони світу (окрім Асоціації держав Південно-Східної Азії.). Також у статті зазначається й обгрунтовується думка, що унікальність (феномен) азіатсько-тихоокеанської економічної інтеграції полягає в наявності м' яких схем інтеграції, які знайшли прояв у формуванні зон економічного зростання у Східній Азії (на прикладі Асоціації держав Південно-Східної Азії, Азіатсько-Тихоокеанського економічного співробітництва). Встановлено, що в регіоні відбувається інтенсивне формування регіональних форумів та механізмів, які сприяють тісним відносинам між основними суб'єктами регіону і посиленню його позицій у світовому політичному процесі. Також у статті виокремлено та проаналізовано тренди політичного регіоналізму в азіатській частині Азіатсько-Тихоокеанського регіону: посилення ролі Китаю в регіональному політичному процесі; співіснування двох моделей співпраці в регіоні: транснаціональну кооперацію та міждержавну конкуренцію; перенесення пріоритету в питаннях регіональної безпеки із зовнішніх загроз на внутрішні, і на перший план виходять аспекти політичної, економічної, соціальної й екологічної співпраці.

Ключові слова: Азіатсько-Тихоокеанський регіон, міжнародні відносини, регіоналізм, інтеграційні процеси, АСЕАН, АТЕС.

\section{Summary}

Myloserdna I. M., Krasnopolska T. M. The Asia-Pacific region and its development projects: the end of the XX - beginning of the XXI century. - Article.

The article is devoted to a comprehensive study of the essence of understanding the concept of "The AsiaPacific region" and analysis of the experience of implementing regional development projects in the modern conditions. It is established that among researchers there is still no single approach to the concept of "APR". The article uses the understanding of "Asia-Pacific" in the narrow sense: the countries of Northeast Asia: China, Japan, South and North Korea and ten countries of Southeast Asia, united in the regional organization ASEAN. All these countries make a significant contribution to interstate relations in the Pacific ocean, so the trends of stability prevail over the trends of destabilization of political and economic processes that form 
the basis of a potential world center. It is established that after the end of the Cold War, the Asia-Pacific region could be considered the most stable region in the world, which has undergone a period of long-term economic development without obvious conflicts. It is noted that the Asia-Pacific region entered the path of development of integration processes much later than other regions of the world (except ASEAN). The article also notes and substantiates the idea that the uniqueness (phenomenon) of Asia-Pacific economic integration lies in the existence of soft integration schemes, which are reflected in the formation of economic growth zones in East Asia (for example, ASEAN, APEC). It is established that in the region there is an intensive formation of regional forums and mechanisms that contribute to the close relationship between the main actors of the region and strengthen its position in the world political process. The article also highlights and analyzes the trends of political regionalism in the Asian part of the Asia-Pacific region: strengthening China's role in the regional political process; coexistence of two models of cooperation in the region: transnational cooperation and interstate competition; shifting priority in regional security from external threats to internal ones, and aspects of political, economic, social and environmental cooperation come to the fore.

Key words: Asia-Pacific region, international relations, regionalism, integration processes, ASEAN, APEC. 